\title{
Sprawozdanie z konferencji naukowej „Wyróżniaj się lub zgiń. Dialog marki z konsumentem" (Katowice, 9 maja 2019)
}

A Report from the Academic Conference „Wyróżniaj się lub zgiń.

Dialog marki z konsumentem"

(Katowice, 9 maja 2019)

9 maja 2019 roku w katowickiej Strefie Centralnej została zorganizowana przez Koło Naukowe „Komunikator” trzecia z cyklu konferencja zatytułowana „Wyróżniaj się lub zgiń”, która z uwagi na tematykę bez wątpienia wpisuje się $w$ nurt wydarzeń naukowo-marketingowych coraz chętniej podejmowanych na uczelniach Górnego Śląska. W poprzednich latach poruszane tematy zasadniczo dotyczyły nowoczesnych form promocji, wizerunku i sposobu jego kreowania. Tegorocznemu spotkaniu przyświecało hasło „Dialog marki z konsumentem", a zasadniczym celem uczestników konferencji było ukazanie postaw osób w sytuacjach komunikacyjnych wyraźnie osadzonych w działaniach marketingowych. I tym razem, podobnie jak we wcześniejszych edycjach, w wydarzeniu wzięli udział liczni specjaliści i naukowcy z dziedziny promocji, kreowania wizerunku, komunikacji społecznej i marketingu. Adresatami spotkania byli zaś studenci, osoby pracujące w branży marketingowej, przedsiębiorcy i hobbiści.

Zaraz po uroczystym otwarciu konferencji jako pierwsza wystąpiła Ewelina Tyc z Uniwersytetu Śląskiego w Katowicach, wiceprezes Stowarzyszenia „Via Linguae”, która w referacie Wizerunek $w$ krzywym zwierciadle (na przykładzie kanału Red Lipstick Monster) omówiła strategie kreowania wizerunku wykorzystywane przez Red Lipstick Monster $w$ mediach społecznościowych. Szczególną uwagę zwróciła na językowe aspekty autopromocji Ewy Grzegorzewskiej-Kostoglu, autorki przywołanego kanału. Następna prelegentka, Agnieszka Ganiek z Uniwersytetu Ekonomicznego w Katowicach, zawodowo związana z Urzędem Miejskim w Mikołowie oraz Fundacją "GaSzo”, w wystąpieniu zatytułowanym Budowanie marki organizacji pozarząowej $w$ kontekście ograniczonych zasobów finansowych zwróciła uwagę na potrzebę działań brandingowych wśród takich organizacji, które obecnie przyczyniają się do wzrostu gospodarczego państwa. Dalszą część panelu wypełniły wystąpienia studentów. Marta Cholewa i Paulina Drobisz z Uniwersytetu Śląskiego w Katowicach, członkinie koła „Komunikator” i działaczki w Samorządzie Studenckim tejże Uczelni, wygłosiły referat pt. Relacja marki z klientem, czyli jak Netflin wykorzystuje real time marketing. Z kolei Joanna Blondzik i Jagoda Głowacka z Uniwersytetu Ekonomicznego $w$ Katowicach $w$ prelekcji zatytułowanej Kampania reklamowa płyty "Małomiasteczkowy" D. Podsiadły, jako przykład wyróżniającej się strategii marketingowej zwróciły szczególną uwagę na ambientowy charakter przywołanej strategii. Zgromadzona publiczność miała 
również okazję zapoznać się z działaniami firmy „Socialpoint.pro”, której przedstawicielki, Magdalena Hoderny-Jeznach i Marta Bral, wyjaśniły, jak skutecznie stawiać pierwsze kroki na Instagramie i dlaczego właśnie z tego medium korzystać $w$ celu budowania wizerunku. Pierwszą część spotkania zakończyło wystąpienie Marka Migalskiego z Uniwersytetu Śląskiego w Katowicach zatytułowane Emocje i ich rola w polityce. Prelegent nie tylko poruszył kwestię wykorzystania emocji $w$ marketingu, lecz także zademonstrował zebranym słuchaczom, jakie strategie budowania historii działają na współczesnego odbiorcę i $w$ jaki sposób tworzyć skuteczną narrację.

Drugą część spotkania otworzyła Anna Ledwoń-Blacha, która na co dzień zajmuje się mediami społecznościowymi w agencji marketingowej „More Bananas”. Prelegentka $w$ swoim wystąpieniu omówiła sposoby skutecznej komunikacji w social mediach. Kolejny referat zatytułowany Red Bull - Content marketing, który dodaje skrzydeł zaprezentowała Maria Bajak z Uniwersytetu Ekonomicznego w Krakowie. W swoich badaniach skupiła się na odbiorze przez konsumentów strategii wizerunkowych marki „RedBull”. W dalszej części spotkania wystąpił Szymon Witczak z Uniwersytetu Śląskiego w Katowicach, przewodniczący koła naukowego „Komunikator”, który w referacie pt. Kreowanie treści $w$ internecie - webwriting przybliżył kilka sposobów na udany przebieg sytuacji komunikacyjnych mających miejsce $w$ nowych mediach. Ukazał też narzędzia do kreowania komunikatów pozwalających skutecznie docierać do potencjalnych użytkowników Sieci. Drugą część spotkania zakończyła prelekcja Wojciecha Orlińskiego, grafika, project menagera, który zawodowo związany jest z marketingiem politycznym. W wystąpieniu zatytułowanym Budowanie wizerunku polityka i partii $w$ mediach społecznościowych poruszył między innymi kwestię doboru koloru i wpływ barwy na odczucia wyborców.

Trzecią część obrad rozpoczęła Agnieszka Nęcka z Uniwersytetu Śląskiego w Katowicach, która wygłosiła referat pt. (Nie)skuteczne strategie komunikacji. Wydział Filologiczny Uniwersytetu Śląskiego w social mediach. Referentka przybliżyła mechanizmy wykorzystywane $w$ celu komunikowania się uczelni ze studentami. Zwróciła uwagę zarówno na zabiegi przynoszące pozytywny odbiór prezentowanego wydziału, jak i na działania, które nie trafiają do potencjalnych odbiorców. W dalszej kolejności referat na temat Marka w pracy muzeum w Polsce. Dlaczego jest tak jak jest? wygłosił Leszek Jodliński, który opisał strategie kreowania marki na przykładzie wybranych muzeów. W swoim wystąpieniu nie tylko zwrócił uwagę na wizerunek osób pracujących $w$ instytucjach kultury, lecz także omówił zagadnienie, jakie wymogi prawne instytucje te stawiają przed osobami chcącymi zajmować się działalnością kulturotwórczą. Następny prelegent, Mikołaj Winkiel z "Brand24”, $w$ swoim wystąpieniu zatytułowanym Dlaczego marki rozmawiają $w$ sieci z klientami zamiast ich olać? zaprezentował aplikacje do monitorowania działalności marki $w$ Internecie. Z referatem pt. Nie tylko Obama - o celebrytyzacji polskiej polityki wystąpiła Agata Kempa z Uniwersytetu Jagiellońskiego. Z kolei prelekcję zatytułowaną Media a wojna informacyjna przedstawił Robert Bryniak z Uniwersytetu Śląskiego w Katowicach. Konferencję zakończyło wystąpienie Konrada Kitaszewskiego z firmy "Jak sprzedawać na LinkedIn”, który referatem zatytułowanym Jak uwolnić potencjał LinkedIn i wykorzystać go $w$ social sellingu wprowadził słuchaczy $w$ tematykę nowego i nieco wymagającego medium społecznościowego specjalizującego się $w$ kontaktach zawodowo-biznesowych. 
Całodniowe spotkanie było okazją do inspirującej wymiany myśli i doświadczeń dotyczących szeroko rozumianej komunikacji nie tylko między prelegentami, lecz także licznie przybyłymi słuchaczami. Tematyka konferencji spotkała się z dużym zainteresowaniem odbiorców, którzy mieli okazję zetknąć się zarówno z pracami doświadczonych praktyków, jak i badaniami teoretyków. Nie zabrakło również świeżego spojrzenia na poruszane kwestie dzięki głosom studentów, którzy chętnie dzielili się swoimi spostrzeżeniami na temat budowania relacji marki z konsumentem we współczesnym świecie. Przygotowane wydarzenie nie wyczerpało jednak potencjału tematycznego poruszanych zagadnień, dlatego też na następny rok organizatorzy zapowiedzieli kolejne spotkanie zogniskowane wokół szeroko pojętej komunikacji. 